\title{
A Comparative Analysis of the Occupational Safety and Health System in Production Systems
}

\author{
BILJANA M. VRANJEŠ, University of Banja Luka, \\ Faculty of Mechanical Engineering, Banja Luka, \\ Bosnia and Herzegovina \\ MLADEN M. TODIĆ, University of Banja Luka, \\ Faculty of Mechanical Engineering, Banja Luka, \\ Bosnia and Herzegovina
}

\author{
Previous announcement \\ UDC: $331.45 / .46$ \\ DOI:10.5937/tehnika1903461V
}

The occupational safety and health system is an integral part of the organization of work and the execution of work processes. This system implies a set of technical and organized measures as well as activities aimed at achieving safety at work, prevention and elimination of hazards/ harmfulness that can cause occupational injuries, occupational and other diseases and the protection of health and work capacity of workers. Many stakeholders participate in the occupational safety and health system. The modern concept of occupational safety implies the active participation of all stakeholders, especially end-users/ workers in the creation and improvement of the occupational safety system.

The lack of research dealing with the perceptions and attitudes of workers about the elements of the system of occupational safety and performance as indicators of the success of this system has initiated the research in two real production systems in the field of industry and mining.

The analysis results can be an important source of information and a basis for the process of continuous improvement in the occupational safety system through the creation of measures to eliminate organizational and functional deficiencies.

Key words: occupational safety and health, performance, workers

\section{INTRODUCTION}

Occupational safety and health is an action organized systemically which achieves the best results when it is an integral part of the organization of work and the execution of work processes. In production systems, occupational safety is organized using basic, special and recognized protection rules in accordance with the general principles of prevention. Occupational safety and health can be defined as a system of technical, health, legal, psychological, pedagogical and other activities that help to detect and eliminate hazards and harmfulness that can endanger life and people's health at work [1]. A well-organized and effi-

Author's address: Biljana Vranješ, University of Banja Luka, Faculty of Mechanical Engineering, Banja Luka, Bulevar vojvode Stepe Stepanovića 71, Bosnia and Herzegovina

e-mail: biljana.vranjes@mf.unibl.org

Paper received: 09.04.2019.

Paper accepted: 15.05.2019. cient system of occupational safety and health is important not only for the purpose of maintaining human potential, but also for a comprehensive development of the country's economy, in which companies are more successful and follow the concept of socially responsible business. Executing occupational safety activities implies a specific organizational structure that combines responsibilities, procedures, processes, resources, and information through the management process. Organizational occupational safety management models are models of:

- vertical or linear management approach,

- horizontal or process management approach, and

- combined or life cycle management approach as a combination of horizontal and vertical approach [2].

The projected engineering process in order to provide occupational safety in accordance with the estimated level of risk, while considering the parameters that enable optimum technical-technological, organizational and other solutions to be selected, is the life 
cycle of occupational safety. The life cycle lasts from the moment when the occupational safety activities begin until the end of the use of the occupational safety system. The stages comprising the cycle are performed periodically [3]: Hazard Analysis and Risk Assessment, Design (analysis and initial evaluation), Implementation, installation, commissioning and continuous validation, Application and maintenance of the system, Modification based on observed irregularities or defects.

An organized occupational safety and health system that is implemented through the application of occupational safety measures should be:

- legally grounded,

- well-organized,

- implemented in a quality manner.

The need for continuous monitoring of the working and living environment, communication of all stakeholders in the process, as well as the application of measures that modify the existing situation and reduce the risk requires a systemic approach, selection and continuous monitoring of performance indicators of the occupational safety system [4]. The quality of occupational safety is assessed based on the performance of occupational safety and performance of the organization, and "measured" by appropriate indicators.

\section{MATERIAL AND METHODS}

This paper deals with the analysis of the practice of organization, implementation and management of occupational safety by being carried out in two real production systems in the field of industry and mining. The sample consists of two companies from the Republic of Srpska (B\&H) whose names for practical and ethical reasons will not be quoted, but they have no relevance to the outcome of the research results. AMP is a limited liability company (mining-production of iron ore) with 800 employees and RNB is a joint-stock company (industry-production and processing of oil and oil derivatives) with 900 employees.

The analysis of the occupational safety and health $(\mathrm{OSH})$ system in these two companies resulted in the following findings:

- In both systems an integrated management system is implemented in accordance with ISO standards (9000, 14000 and 18000),

- The integrated management system and the management system of occupational safety and health is established on the basis of process approach with line management from top to bottom,

- Occupational safety and health activities in both systems are organized within a separate Service, because they are systems with a large number of employees, although this is not legally defined.

An important difference in the way the OSH system is organized in these production systems is:

- At AMP, the occupational safety function is under the direct management of the director above other production functions, and the activities are carried out according to the established model with elaborated processes (Figure 1)

- The function of occupational safety in the RNB is by organizational structure at the hierarchical level of other business functions or within the process of supporting production functions. The occupational safety management process has not been further elaborated as sub-processes.

- RNB has not organized a Committee on occupational safety and health that has the role of an advisory body composed of management representatives and workers whose task is to improve the state of occupational safety and health, which is a legal obligation.

The model of functioning of the occupational safety system in the AMP production system through established process activities is shown in Figure 1.

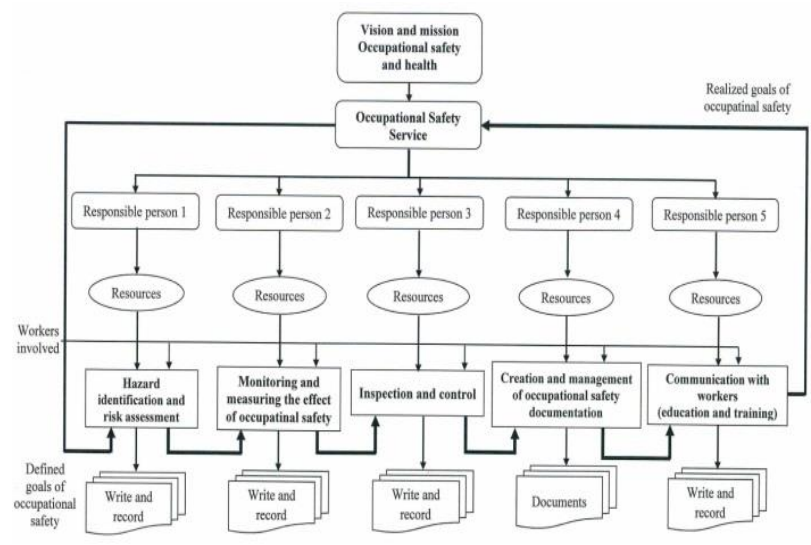

Figure 1 - Model of occupational safety and health system at $A M P$

The aim of the research was to find out whether in the production system in which there is a model of occupational safety with determined process activities, this model influences the state of occupational safety. The research is to prove the hypothesis that there is a connection between the established model of the occupational safety and health system in the production system and the state of the occupational safety and health established therein.

By examining a representative sample by the survey, the factual situation of the occupational safety and health system was determined based on workers' subjective opinions (specific and experiential) as direct participants in the system of occupational safety. Respondents-workers in the two production systems were 
presented with an opinion on the state and the elements of occupational safety and health system, and the workers were required to present their assessment and opinions, and then the obtained workers' responses were compared.

The survey was conducted in 2018, with 300 respondents from AMP and 472 from RNB, which means a total of 772 respondents.

A written descriptive-analytical questionnaire was used as a research instrument, which was filled in by respondents in researcher's presence. The survey was conducted voluntarily and anonymously for respondents. Survey questions were grouped into four groups based on independent and dependent variables:

- Independent variables: Worker's profile, The occupational safety and health system in the organization and Work of the Committee on occupational safety and health

- Dependent variables: The state (performance) of occupational safety and health in the organization

The questions are closed type with the offered answers, one of which can be selected. The opinion of the questions raised (subjective) and their aswsessment of the presented claims were given by the workers/ respondents according to the Likert scale of intensity of 5 responses offered: 1 . I totally disagree, 2 . I mostly disagree, 3. I do not know (I neither agree nor disagree), 4. I mostly agree and 5. I totally agree.

The variable The state (performance) of occupational safety and health in the organization is graded according to the intensity scale of 3 offered responses.

Descriptive statistics was used for statistical processing of basic data on the profile of the worker-respondent, while analytical statistics was used to process the respondents' opinion.

Statistical indicators were used for statistical analysis: $\mathrm{N}$ - frequency, $\%$ - percentage, $\Sigma$ - sum, M arithmetic mean, $\sigma$ - standard deviation, V\% - coefficient of variability, coefficient of correlation (Spearman rho) and correlation matrix, nonparametric tests: Kolmogorov - Smirnov, Mann Whitney U, Kruskal Wallisov H, reliability check (Cronbach's Alpha) and verification of the distribution normality.

Data were prepared for processing in Microsoft Excel and statistical processing in the IBM SPSS Statistics 23 software package.

\section{RESULTS AND DISCUSSION}

The sample structure at the frequency level is: In company AMP:

- Gender: men - 251 (81.7\%) and women 49 $(16.3 \%)$,
- $\quad$ Age: up to 30 years - 30 (10\%), from 31 to 40 - 97 (32.3\%), from 41 to $50-48(16 \%)$, from 51 to 60 - $109(36.3 \%)$ and over 60 years - $16(5.3 \%)$,

- Level of education: high school - 228 (76\%), college - $21(7 \%)$, higher education (graduate engineers ) - $49(16.3 \%)$ and masters - $2(0.7 \%)$,

- Total work experience: up to 5 years - $18(6 \%)$, from 6 to $10-83(27.7 \%)$, from 11 to $20-63$ (21\%), from 21 to $30-22(7.3 \%)$ and over 60 years - $114(38 \%)$.

In company RNB:

- Gender: men - $391(82.8 \%)$ and women 81 (17.2\%),

- $\quad$ Age: up to 30 years - $43(9.1 \%)$, from 31 to 40 $145(30.7 \%)$, from 41 to $50-153(32.4 \%)$, from 51 to $60-129(27.3 \%)$ and over 60 years - 2 $(0.4 \%)$,

- Level of education: primary school - $11(2.3 \%)$, high school - 414 (87.7\%), college - 21 (4.4\%), higher education (graduate engineers) - $25(5.3 \%)$ and masters - $1(0.2 \%)$,

- Total work experience: up to 5 years - $16(3.4 \%)$, from 6 to $10-70(14.8 \%)$, from 11 to $20-173$ $(36.7 \%)$, from 21 to $30-149(31.6 \%)$ and over 30 years - 64 (13.6\%).

According to descriptive analysis the mean value of the variables group The occupational safety and health system in the organization (28 individual variables) in both companies is more than four (AMP $\mathrm{AS}=4.09$; RNB AS=4.04), which is a high grade and indicates workers' satisfaction with the achieved degree of occupational safety and health. In both companies, the same variable was rated by the highest grade Our organization carries out regular medical examinations of all workers (AMP $\mathrm{AS}=4.60$; RNB $\mathrm{AS}=4.60$ ), respectively to, with the lowest rating Management does not blame workers in case of a safety incident (AMP AS = 3.71; RNB AS = 3.29). Based on the assessment of the workers on individual variables that describe the occupational safety and health system, we can conclude that it is rather difficult to investigate and determine the responsibility for events that jeopardize safety.

According to descriptive analysis the mean value of the variables group The state (performance) of occupational safety and health in the organization $(8$ individual variables) in conpany AMP is AS $=1.97$, and in company RNB is AS $=1.91$. Variable Assessment of the participation of workers in the organization's occupational safety and health system in company AMP (AS = 2.18) was rated by the highest grade which it can be linked to the workers' satisfaction with their role and participation in the work of the Committee on occupational safety and health. In 
the RNB company variable Assessment of training and education in the organization's occupational safety and health ( $\mathrm{AS}=2.20$ ) was rated by the highest grade, the workers of this company consider the manner and quality of training for occupational safety as the most important performance. The variable Assessment of the work of the trade union organization in both companies (AMP AS $=1.77$; RNB AS $=1.40$ ) was rated by the lowest grade, which leads to the conclusion that workers do not perceive the work of trade unions as a way of exercising their rights, among others the right on occupational safety and health.

The reliability of the research instruments was checked using the Kronbach alpha coefficient, the recommended value of which was greater than 0.7 [5]. The reliability established for the measurement scale of the variable The occupational safety and health system in the organization is 0.950 (company AMP) and 0.957 (company RNB). According to the Kronbach's alpha coefficient, the reliability of the measurement scale of the variable The state (performance) of occupational safety and health in the organization is 0.866 (company AMP) and 0.844 (company RNB).

Kolmogorov-Smirnov's normality test of variance was used to verify normal distribution of variables (Table 1).

Table 1. Deviation of distribution of results from normal distribution within selected research variables

\begin{tabular}{|c|c|c|c|c|c|}
\hline \multicolumn{6}{|c|}{ Tests of Normality } \\
\hline & & \multicolumn{2}{|c|}{$\begin{array}{l}\text { Kolmogorov- } \\
\text { Smirnov }^{\mathrm{a}}\end{array}$} & \multicolumn{2}{|c|}{ Shapiro-Wilk } \\
\hline & & Statistic & Sig. & \multicolumn{2}{|c|}{ Statistic Sig. } \\
\hline & & \multicolumn{2}{|c|}{$\mathrm{df}=300$} & \multicolumn{2}{|c|}{$\mathrm{df}=300$} \\
\hline \multirow{3}{*}{ 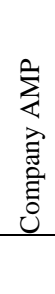 } & $\begin{array}{l}\text { The occupational safety } \\
\text { and health system in the } \\
\text { organization }\end{array}$ & .127 & .000 & .910 & .000 \\
\hline & $\begin{array}{l}\text { The state (performance) of } \\
\text { occupational safety and }\end{array}$ & .153 & .000 & .968 & .000 \\
\hline & & \multicolumn{2}{|c|}{$\mathrm{df}=300$} & \multicolumn{2}{|c|}{$\mathrm{df}=300$} \\
\hline \multirow{2}{*}{ 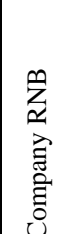 } & $\begin{array}{l}\text { The occupational safety } \\
\text { and health system in the } \\
\text { organization }\end{array}$ & .070 & .000 & .957 & .000 \\
\hline & $\begin{array}{l}\text { The state (performance) of } \\
\text { occupational safety and } \\
\text { health in the organization }\end{array}$ & .167 & .000 & .958 & .000 \\
\hline
\end{tabular}

Based on the results in Table 1, we conclude that the condition of normality is not satisfied, so the transformation of the research variables (adjustment to the normal distribution) is made, and in a further statistical analysis used of non-parametric statistics.
Results of descriptive statistics of transformed variables for the whole sample are shown in Table 2.

Table 2. Results of descriptive statistics for transformed research variables

\begin{tabular}{|c|c|c|c|c|c|}
\hline \multicolumn{6}{|c|}{ Descriptive Statistics } \\
\hline \multicolumn{2}{|c|}{ Variables } & \multirow{2}{*}{ Min } & \multirow{2}{*}{ Max } & \multirow{2}{*}{ Mean } & \multirow{2}{*}{$\frac{\sigma}{17.053}$} \\
\hline \multirow{3}{*}{ 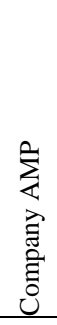 } & $\begin{array}{l}\text { The occupational safety and } \\
\text { health system in the organization }\end{array}$ & & & & \\
\hline & $\begin{array}{l}\text { The state (performance) of } \\
\text { occupational safety and health in } \\
\text { the organization }\end{array}$ & 8 & 24 & 16.36 & 3.140 \\
\hline & \multicolumn{5}{|l|}{ Valid $N($ listwise $)=300$} \\
\hline & $\begin{array}{l}\text { The occupational safety and } \\
\text { health system in the organization }\end{array}$ & 49 & 140 & 113.12 & 17.8 \\
\hline 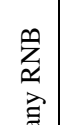 & $\begin{array}{l}\text { The state (performance) of } \\
\text { occupational safety and health in } \\
\text { the organization }\end{array}$ & 8 & 24 & 15.29 & 2.882 \\
\hline
\end{tabular}

A higher average value was determined on a scale of variables The occupational safety and health system in the organization which reflects the function and activities of occupational safety and health for workers in relation to the variable that reflects the state of occupational safety and health in the organization (AMP AS = 114.42; RNB AS = 113.12).

To analyze the statistical significance of variations among variables, the nonparametric Mann Whitney U test was used to compare the variables with two variable scales and the Kruskal Wallis $H$ test for variables with three or more variables on a scale. The results of the Mann Whitney $U$ test and the Kruskal Wallis $\mathrm{H}$ tests for research variables are shown in Tables 3-6.

Table 3. Ranges of values of groups of variables in relation to the company

\begin{tabular}{|c|c|c|c|c|}
\hline \multicolumn{5}{|l|}{ Ranks } \\
\hline \multicolumn{2}{|l|}{ Company } & $\mathrm{N}$ & $\begin{array}{l}\text { Mean } \\
\text { Rank }\end{array}$ & $\begin{array}{l}\text { Sum of } \\
\text { Ranks }\end{array}$ \\
\hline \multirow{3}{*}{$\begin{array}{l}\text { The occupational safety } \\
\text { and health system in the } \\
\text { organization }\end{array}$} & $\begin{array}{l}\text { Company } \\
\text { AMP }\end{array}$ & 300 & 400.54 & 120162.50 \\
\hline & $\begin{array}{l}\text { Company } \\
\text { RNB }\end{array}$ & 472 & 377.58 & 178215.50 \\
\hline & Total & 772 & & \\
\hline \multirow{3}{*}{$\begin{array}{l}\text { The state (performance) of } \\
\text { occupational safety and } \\
\text { health in the organization }\end{array}$} & $\begin{array}{l}\text { Company } \\
\text { AMP }\end{array}$ & 300 & 441.67 & 132501.00 \\
\hline & $\begin{array}{l}\text { Company } \\
\text { RNB }\end{array}$ & 472 & 351.43 & 165877.00 \\
\hline & Total & 772 & & \\
\hline
\end{tabular}


Table 4. Results of Mann Whitney $U$ test for research variables: company

\begin{tabular}{|c|c|c|}
\hline \multicolumn{3}{|l|}{ Test Statistics ${ }^{\mathrm{a}}$} \\
\hline Company & $\begin{array}{l}\text { The occupational } \\
\text { safety and health } \\
\text { system in the } \\
\text { organization }\end{array}$ & $\begin{array}{l}\text { The state (performance) } \\
\text { of occupational safety } \\
\text { and health in the } \\
\text { organization }\end{array}$ \\
\hline $\begin{array}{l}\text { Mann-Whitney } \\
\text { U }\end{array}$ & 66587.500 & 54249.000 \\
\hline Wilcoxon W & 178215,500 & 165877.000 \\
\hline$z$ & -1.395 & -5.532 \\
\hline $\begin{array}{l}\text { Asymp. Sig. (2- } \\
\text { tailed) }\end{array}$ & .163 & .000 \\
\hline a. Grouping Varia & iable: company & \\
\hline
\end{tabular}

The results of the Mann-Whitney U test (Table 4) showed there was a statistically significant difference for the variable The state (performance) of occupational safety and health in the organization, as the
AMP workers showed a statistically significantly higher mean rank of $<0.01$ in relation to the workers of RNB. The Mann Whitney U test showed a statistically significant difference for state of occupational safety and health of the AMP workers $(\mathrm{Md}=16, \mathrm{~N}=$ 300) and RNB's workers $(\mathrm{Md}=15, \mathrm{~N}=472)$; $\mathrm{U}=$ 54249, $\mathrm{z}=-5.53, \mathrm{p}=0.0, \mathrm{r}=0.2$.

The workers from AMP, where there is a defined model of functioning of the occupational safety and health system, evaluated more highly occupational safety conditions (assessing a better state of occupational safety) than workers from the RNB company where this model does not exist.

It was pointed out earlier that in the company RNB the Committee on occupational safety and health was not formed, and in the AMP company where there are $82.3 \%$ of workers/ respondents it was declared that its work was satisfactory.

Table 5. The ranking of the variables values in relation to the Work of the Committee on occupational safety and health

\begin{tabular}{|c|c|c|c|c|}
\hline \multicolumn{5}{|l|}{ Ranks } \\
\hline & & Quality of work of the Committee on occupational safety and health & $\mathrm{N}$ & Mean Rank \\
\hline \multirow{5}{*}{ 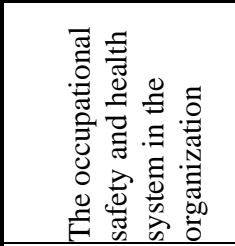 } & RNB & There is no Committee on occupational safety and health & 472 & 236.50 \\
\hline & \multirow{4}{*}{$\sum_{<}^{\&}$} & The work of the Committee on occupational safety and health is bad & 27 & 77.15 \\
\hline & & The work of the Committee on occupational safety and health is satisfactory & 245 & 150.42 \\
\hline & & The work of the Committee on occupational safety and health is at a high level & 28 & 221.96 \\
\hline & & Total & 300 & \\
\hline \multirow{5}{*}{ 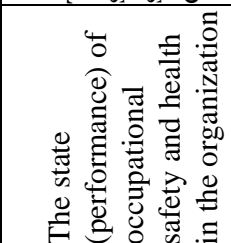 } & RNB & There is no Committee on occupational safety and health & 472 & 236.50 \\
\hline & \multirow{4}{*}{$\sum_{<}^{q}$} & The work of the Committee on occupational safety and health is bad & 27 & 44.41 \\
\hline & & The work of the Committee on occupational safety and health is satisfactory & 245 & 148.41 \\
\hline & & The work of the Committee on occupational safety and health is at a high level & 28 & 271.09 \\
\hline & & Total & 300 & \\
\hline
\end{tabular}

Table 6. Results of the Kruskal Wallis test for research variables: work of the Committee on occupational safety and health

\begin{tabular}{|l|l|l|}
\hline \multicolumn{2}{|l|}{ Test Statistics ${ }^{\mathrm{a}, \mathrm{b}}$} \\
\hline AMP & $\begin{array}{l}\text { The occupational } \\
\text { safety and health } \\
\text { system in the } \\
\text { organization }\end{array}$ & $\begin{array}{l}\text { The state (performance) of } \\
\text { occupational safety and } \\
\text { health in the organization }\end{array}$ \\
\hline $\begin{array}{l}\text { Chi- } \\
\text { Square }\end{array}$ & 38.336 & 96.746 \\
\hline df & 2 & 2 \\
\hline $\begin{array}{l}\text { Asymp. } \\
\text { Sig. }\end{array}$ & $\mathbf{. 0 0 0}$ \\
\hline \begin{tabular}{l} 
a. Kruskal Wallis Test \\
\hline \\
b. Grouping Variable: work of the Committee on occupational safety \\
and health
\end{tabular} \\
\hline \multicolumn{2}{|c|}{ Median } \\
\hline
\end{tabular}

\begin{tabular}{|c|c|c|c|}
\hline \multicolumn{2}{|c|}{$\begin{array}{l}\text { Work of the Committee on } \\
\text { occupational safety and health }\end{array}$} & $\begin{array}{l}\text { The } \\
\text { occupational } \\
\text { safety and healtt } \\
\text { system in the } \\
\text { organization }\end{array}$ & $\begin{array}{l}\text { The state } \\
\text { (performance) of } \\
\text { hoccupational safety } \\
\text { and health in the } \\
\text { organization }\end{array}$ \\
\hline \multirow{4}{*}{ AMP } & The work is bad & 98.00 & 11.00 \\
\hline & $\begin{array}{l}\text { The work is } \\
\text { satisfactory }\end{array}$ & 117.00 & 16.00 \\
\hline & $\begin{array}{l}\text { The work is at a } \\
\text { high level }\end{array}$ & 126.00 & 22.50 \\
\hline & Total & 117.50 & 16.00 \\
\hline
\end{tabular}

The results of the Kruskal Wallis test (Table 6) showed that there was a statistically significant difference in variables in the AMP company at a significance level of $<0.01$. From the results of the test, it is noticeable that a statistically significant difference was established on the variable The work of the Committee on occupational safety and health is at a high level. This indicates that the quality of the Committee's work as an advisory body with the function of delegating guidelines for the improvement 
of the occupational safety and health system in which workers are actively involved significantly influences all of the established research variables chosen as important for defining the system and the state of occupational safety and health in the company, and the choice of performance to manage this system.

Before determining correlations between variables, a scattering diagram was used for a rough estimation of the strength of the correlations. A strong correlation it indicated by the accumulation of points around the imaginary line (Figure 2).

Figure 2 shows that the increase on the scale of The occupational safety and health system in the organization is followed by rise on the scale of The state (performance) of occupational safety and health in the organization. A better assessment of individual variables that characterize the way of functioning and the activities of the occupational safety and health system in the production system is accompanied by a better assessment of the state occupational safety and health. The value of $\mathrm{R}^{2}=0.318$ shows that $31.8 \%$ of the change in the variable of The state (performance) of occupational safety and health in the organization is explained by the linear model.

Using the non-parametric Spirman correlation coefficient, with the recommended value for strong correlation 0.5 to $1[5,6]$, we obtain a correlation matrix of variables (Table 10). The author [7] of the correlation in the range of 0.4 to 0.7 defines as a significant correlation.

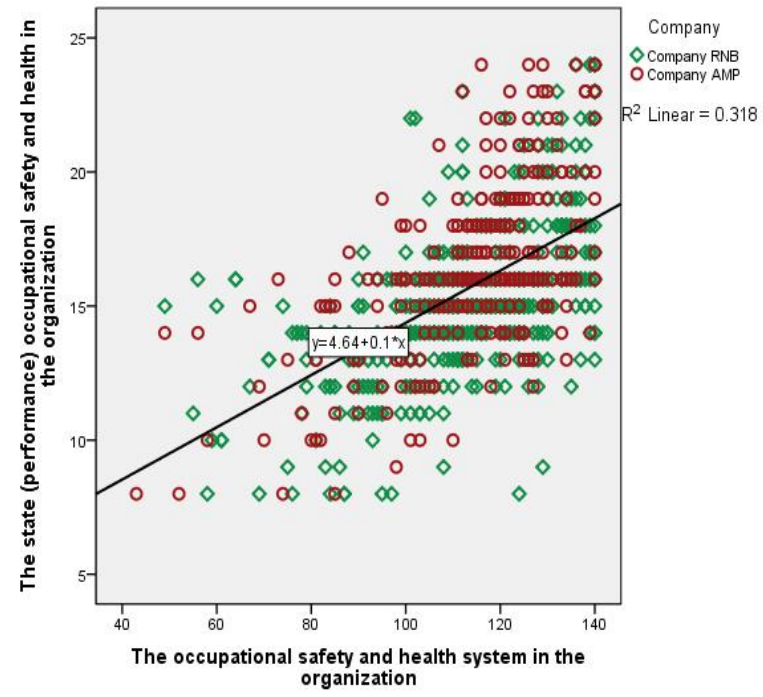

Figure 2 - Positive interconnection of the variables The occupational safety and health system in the organization and variables The state (performance) of occupational safety and health in the organization on a scatter diagram

Table 7. Correlation matrix of the relationship of variables

\begin{tabular}{|c|c|c|c|c|c|}
\hline \multicolumn{6}{|c|}{ Correlations } \\
\hline \multicolumn{4}{|c|}{ Company } & $\begin{array}{l}\text { The occupational safety and } \\
\text { health system in the } \\
\text { organization }\end{array}$ & $\begin{array}{l}\text { The state (performance) of } \\
\text { occupational safety and } \\
\text { health in the organization }\end{array}$ \\
\hline \multirow{8}{*}{ 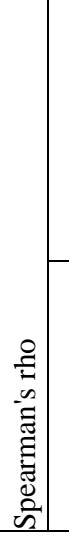 } & \multirow{4}{*}{ 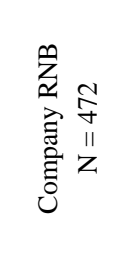 } & \multirow{2}{*}{$\begin{array}{l}\text { The occupational safety and health } \\
\text { system in the organization }\end{array}$} & Corr. Coeff. & 1.000 & $.558^{* *}$ \\
\hline & & & Sig. (2-tail.) & . & .000 \\
\hline & & \multirow{2}{*}{$\begin{array}{l}\text { The state (performance) of occupational } \\
\text { safety and health in the organization }\end{array}$} & Corr. Coeff. & $.558^{* *}$ & 1.000 \\
\hline & & & Sig. (2-tail.) & .000 & . \\
\hline & \multirow{4}{*}{ 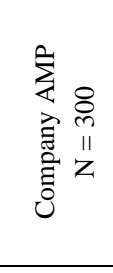 } & \multirow{2}{*}{$\begin{array}{l}\text { The occupational safety and health } \\
\text { system in the organization }\end{array}$} & Corr. Coeff. & 1.000 & $.510^{* * *}$ \\
\hline & & & Sig. (2-tail.) & . & .000 \\
\hline & & \multirow{2}{*}{$\begin{array}{l}\text { The state (performance) of occupational } \\
\text { safety and health in the organization }\end{array}$} & Corr. Coeff. & $.510^{* *}$ & 1.000 \\
\hline & & & Sig. (2-tail.) & .000 & . \\
\hline
\end{tabular}

The correlation matrix (Table 7) shows a statistically significant correlation between variables at a significance level of $<0.01$. The strengths of the established correlations are at the level of strong positive (0.5 to 1), i.e. significant positive correlation (from 0.4 to 0.7 ). Based on Spearman's correlation, we conclude that The occupational safety and health system in the organization explains $26.01 \%(0.51 \times 0.51=0.2601)$ of variance in workers' responses on the scale The state (performance) of occupational safety and health in the organization in the company AMP and $31.14 \%(0.58 \mathrm{x}$ $0.58=0.3314)$ of variance in the RNB company. 
Table 8. Correlation matrix of the relationship of variable The state (performance) of occupational safety and health in the organization

\begin{tabular}{|c|c|c|c|c|}
\hline \multirow{2}{*}{\multicolumn{2}{|c|}{ Company }} & & $\begin{array}{l}\mathrm{AMP} \\
\mathrm{N}=300\end{array}$ & $\begin{array}{l}\mathrm{RNB} \\
\mathrm{N}=472\end{array}$ \\
\hline & & & \multicolumn{2}{|c|}{$\begin{array}{l}\text { The state (performance) of occupational } \\
\text { safety and health in the organization }\end{array}$} \\
\hline \multirow{2}{*}{\multicolumn{2}{|c|}{$\begin{array}{l}\text { Assessment of the state of occupational health and safety in the } \\
\text { organization zaciji }\end{array}$}} & Corr. Coeff. & $.664^{* *}$ & $.617^{* *}$ \\
\hline & & Sig. (2-tail.) & .000 & .000 \\
\hline \multirow{2}{*}{\multicolumn{2}{|c|}{$\begin{array}{l}\text { Assessment of financial investments of the organization in the } \\
\text { occupational safety and health }\end{array}$}} & Corr. Coeff. & $.595^{* *}$ & $.665^{* *}$ \\
\hline & & Sig. (2-tail.) & .000 & .000 \\
\hline \multirow{2}{*}{\multicolumn{2}{|c|}{$\begin{array}{l}\text { Assessment of management participation in the organization's } \\
\text { occupational health and safety system }\end{array}$}} & Corr. Coeff. & $.704^{* *}$ & $.686^{* *}$ \\
\hline & & Sig. (2-tail.) & .000 & .000 \\
\hline \multirow{2}{*}{\multicolumn{2}{|c|}{$\begin{array}{l}\text { Assessment of the participation of workers in the organization's } \\
\text { occupational safety and health system }\end{array}$}} & Corr. Coeff. & $.624^{* *}$ & $.611^{* * *}$ \\
\hline & & Sig. (2-tail.) & .000 & .000 \\
\hline \multirow{2}{*}{\multicolumn{2}{|c|}{$\begin{array}{l}\text { Assessment of training and education in the organization's } \\
\text { occupational safety and health }\end{array}$}} & Corr. Coeff. & $.696^{* *}$ & $.601^{* *}$ \\
\hline & & Sig. (2-tail.) & .000 & .000 \\
\hline \multirow{2}{*}{\multicolumn{2}{|c|}{ Assessment of the work of the trade union organization }} & Corr. Coeff. & $.726^{* *}$ & $.597^{* *}$ \\
\hline & & Sig. (2-tail.) & .000 & .000 \\
\hline \multirow{2}{*}{\multicolumn{2}{|c|}{$\begin{array}{l}\text { Assessment of the work of the Occupational safety service in the } \\
\text { organization }\end{array}$}} & Corr. Coeff. & $.723^{* *}$ & $.695^{* *}$ \\
\hline & & Sig. (2-tail.) & .000 & .000 \\
\hline \multirow{2}{*}{\multicolumn{2}{|c|}{$\begin{array}{l}\text { Dialogue/ cooperation between employers, trade unions, workers' } \\
\text { representatives, workers and inspections in the area of occupational } \\
\text { s safety and health }\end{array}$}} & Corr. Coeff. & $.779^{* * *}$ & $.731^{* * *}$ \\
\hline & & Sig. (2-tail.) & .000 & .000 \\
\hline \multirow{2}{*}{\multicolumn{2}{|c|}{$\begin{array}{l}\text { The state (performance) of occupational safety and health in the } \\
\text { organization }\end{array}$}} & Corr. Coeff. & 1.000 & 1.000 \\
\hline & & Sig. (2-tail.) & . & . \\
\hline
\end{tabular}

Table 8 shows the established strong positive correlation, i.e. significant and high or very high positive correlation (correlation value from 0.7 to 1 [7]) for all individual variables The state (performance) of occupational safety and health in the organization. The strongest correlation was determined for the variable Dialogue/cooperation between employers, trade unions, representatives of workers, workers and inspection in the area of occupational safety and health, hence, we can conclude that in the companies, a dialogue culture related to occupational safety issues has been established. This variable explains $60.68 \%(0.779$ $x$ 0.779) variance in workers' responses to the scale of The state (performance) of occupational safety and health in the organization in the AMP company, and $53.74 \%(0.731 \times 0.731)$ variance in the RNB company. This result leads to conclusion that the workers consider the active participation of all stakeholders in the occupational safety and health system as important for the functioning of the occupational safety and health system in the production systems.

\section{CONCLUSION}

Every occupational safety and health system, more or less organized, should be subject to optimization through the application of new methods and techniques in order to increase its efficiency and achieve a higher level of occupational safety. By using an example of two real production systems, this research has shown which indicators and criteria that the occupational safety and health system is based on are to be monitored in the working environment.

The production system in which the management of occupational health and safety takes place according to a certain model with elaborated processes and determined organizational structure has higher quality of the state of the working environment and is more efficient. A statistically significant difference in the responses of the AMP workers/ respondents about the state of occupational safety and health in the organization confirms this.

The existence of the Committee on occupational safety and health at the AMP company and a statistically significant difference established in The work of the Committee on occupational safety and health is at a high level show that it is an important element for the functioning of the occupational safety and health system in the form of achieved performance.

Higher values of correlation variables that define the state (performance) of occupational safety and 
health established in the AMP company prove that the established model of occupational safety organization, in relation to the RNB enterprise where it does not exist, has an impact on the results achieved in the field of occupational safety.

This research could be applied to other companies, with an emphasis on small and medium-sized companies with the aim of determining the specificity of the management of occupational safety and health systems in such companies, taking into account the fact that our economic reality indicates that there are increasingly fewer production systems with large numbers workers.

\section{REFERENCES}

[1] Palačić D, The effect of OHSAS 18001 and ISO 14001 standards application on improvement of quality performance of working and livingenvironment, $\mathrm{PhD}$ dissertation, University of Niš, Faculty of Occupational Safety in Niš, Niš, 2015.

[2] Knegtering B, Safety lifecycle management in the process industries: the development of a qualitative safety-related information analysis technique, Eindhoven: Technische Universiteit Eindhoven, 2002.

[3] Bergstrom J, Safety instrumented systems and safety life cycle, Process Engineering Associates, LLC, 2009. [quoted 13. 11. 2018] available at www.ProcessEngr.com,

[4] Janaćković G, Models for integrated safety system management based on collaborativework, PhD dissertation, University of Niš, Faculty of Occupational Safety in Niš, Niš, 2015.

[5] Pallant J, SPSS Survival Manual: A Step by Step Guide to Data Analysis Using SPSS for Windows (Version 15), Allen \& Unwin, 2007.

[6] Aranđelović I, Mitrović Z, Stojanović V. Probability and Statistics, Belgrade Institute for Textbooks, Belgrade, 2011.

[7] Petz B, Basic statistical methods for non-mathematicians, Edition Waterfall, Zagreb, 1997.

\section{REZIME}

\section{KOMPARATIVNA ANALIZA SISTEMA ZAŠTITE NA RADU U PROIZVODNIM SISTEMIMA}

Sistem zaštite i zdravlja na radu je sastavni deo organizacije rada i izvođenja radnih procesa. Ovaj sistem podrazumjeva skup tehničkih i organizovanih mjera i aktivnosti usmjerenih na ostvarivanje: bezbjednosti na radu, sprečavanje i otklanjanje opasnosti/ štetnosti koje mogu prouzrukovati povrede na radu, profesionalne $i$ druge bolesti i zaštitu zdravlja i radne sposobnosti radnika. U sistemu zaštite $i$ zdravlja na radu učestvuju mnoge zainteresovane strane (stejkholderi). Savremeni koncept zaštite na radu podrazumjeva aktivno učešće svih zainteresovanih strana, a posebno krajnjih korisnika/ radnika u kreiranju i unaprijeđenju sistema zaštite.

Nedostatak istraživanja koja obrađuju percepcije $i$ stavove neposrednih izvršilacal radnika o elementima sistema zaštite na radu i performansama kao pokazateljima uspješnosti tog sistema je inicirao sprovođenje istraživanja u dva realna proizvodna sistema iz oblasti industrije i rudarstva.

Rezultati analize mogu biti važan izvor informacija i osnova za proces kontinuiranih poboljšanja $u$ sistemu zaštite, kroz kreiranje mjera za otklanjanje organizacionih i funkcionalnih nedostataka.

Ključne riječi: sistem zaštite na radu, radnici, performanse 